\title{
Successful treatment of cardiogenic shock with an intra- aortic balloon pump following aluminium phosphide poisoning
}

\author{
Omid Mehrpour ${ }^{1,2,3}$, Ahmad Amouzeshi ${ }^{4,5}$, Bita Dadpour ${ }^{3}$, Zohreh Oghabian ${ }^{6}$, Nasim Zamani ${ }^{7}$, \\ Shahram Amini ${ }^{8}$, and Robert S. Hoffman ${ }^{9}$ \\ Atherosclerosis and Coronary Artery Research Center ${ }^{I}$, Medical Toxicology and Drug Abuse Research \\ Center (MTDRC) ${ }^{2}$, Department of Cardiac Surgery ${ }^{4}$,Birjand University of Medical Sciences, Birjand, \\ Addiction Research Centre ${ }^{3}$, Department of Cardiac Surgery ${ }^{5}$, Department of Anesthesiology ${ }^{8}$, Mash had \\ University of Medical Toxicology Sciences, Mashhad, Department of Clinical Toxicology, Kerman \\ University of Medical Sciences, Kerman ${ }^{6}$, Department of Clinical Toxicology, Loghman Hakim Hospital, \\ Shahid Beheshti University of Medical Sciences, Tehran', Iran, Division of Medical Toxicology, Department \\ of Emergency Medicine, NYU School of Medicine, Bellevue Hospital Center, NY, USA ${ }^{9}$
}

\author{
Received in May 2013 \\ CrossChecked in May 2013 \\ Accepted in September 2013
}

\begin{abstract}
Aluminium phosphide (AlP) is a highly toxic pesticide that inhibits cytochrome oxidase $\mathrm{c}$ and causes oxidative stress. Death results from refractory cardiogenic shock due to myocardial dysfunction. There is very little information regarding extracorporeal life support in severe AlP poisoning. Although several therapies are available, none are curative. We report on the use of an intra-aortic balloon pump (IABP) in a 24-year-old woman brought to our hospital after an intentional ingestion of a tablet of AlP (3 g), which caused refractory AlP-induced cardiogenic shock and acute respiratory distress syndrome (ARDS). The patient underwent gastric lavage with potassium permanganate, received sodium bicarbonate intravenously, and was admitted to the intensive care unit. Echocardiography at $36 \mathrm{~h}$ post ingestion showed a left ventricular ejection fraction (LVEF) of $<20 \%$. An IABP was inserted and the patient's vital signs stabilised. After eight days, the IABP was removed and on day 20 , the patient's LVEF increased to $50 \%$. IABP was successfully used and may improve future prognoses for severely poisoned AlP patients with refractory cardiogenic shock. We encourage clinical toxicologists to examine this new treatment.
\end{abstract}

KEY WORDS: emergency medical treatment; extracorporeal life support; phosphine gas poisoning

Aluminium phosphide (AlP) is an extremely efficient substance used as both an outdoor and indoor pesticide (1-5). It is easily available in Asian countries such as India and Iran, where it is also known as "rice tablet" because of its frequent use in the protection of stored rice and grains from rodents and other household pests (6). Many cases of suicide attempts have been reported with rice tablets in these countries $(3,5)$. In fact, AlP is generally the most commonly used fatal intentional poison in Iran and India (3, 7, 8). AlP poisoning leads to multiorgan failure $(9,10)$, but death following this poisoning is most often caused by refractory hypotension and cardiogenic shock in the form of toxic chemical myocarditis, which leads 
to severe left ventricular dysfunction $(8,11,12)$. The exact mechanism of its toxicity is unclear, but the release of phosphine gas as well as cytochrome oxidase inhibition, oxidative stress, and free oxygen radicals have been suggested as the main causes of toxicity $(8,13)$. Unfortunately, there is no specific antidote and all treatments, such as gastric lavage with potassium permanganate, administration of coconut oil (14), etc., are only supportive procedures. Refractory hypotension is generally managed by early resuscitation with fluid and vasoactive agents (norepinephrine or phenylephrine, dopamine, and dobutamine). Moreover, Vitamins C and E (3), hyperbaric oxygenation (15), N-acetyl cysteine (16), digoxin (11), and recently intra-aortic balloon pump (IABP) (12) have been used to treat toxic myocarditis due to rice tablet poisoning.

AlP is highly reactive and any contact with moisture will result in decomposition to phosphine gas. Phosphine poisoning has a mortality rate as high as $70-100 \%(9,10,17)$. Its main mechanism of toxicity is the inhibition of cytochrome oxidase $\mathrm{c}$ and oxidative stress $(8,13,18)$. As a result, AlP poisoning can cause refractory cardiogenic shock and metabolic acidosis (8). Currently, there is no specific antidote for AlP poisoning and treatment is only supportive. This paper reports a successful treatment of AlPinduced cardiogenic shock using an IABP in a 24-yearold woman.

\section{Case report}

The Imam Reza hospital in Mashhad, Iran is the referral hospital for poisoned patients in Eastern Iran and one of the largest toxicology hospitals in the world $(19,20)$. A 24-year-old woman who had intentionally ingested one three-gram tablet of aluminium phosphide (AlP) was referred to our hospital and admitted to the Toxicology Emergency Department. She ingested the tablet with four glasses of water, vomited immediately, and was presented fully conscious to a local hospital complaining of weakness, cold extremities, and thirst. The patient's initial vital signs were as follows: blood pressure $90 / 50 \mathrm{~mm} \mathrm{Hg}$; pulse rate $120 \mathrm{bpm}$; respiratory rate 20 per minute; and body temperature $37.1{ }^{\circ} \mathrm{C}$, with an oxygen saturation of $96 \%$ at room air. Initial blood gas analysis showed a pH of 7.39; $\mathrm{PCO}_{2} 21.2 \mathrm{~mm} \mathrm{Hg}$; $\mathrm{PaO}_{2} 59 \mathrm{~mm} \mathrm{Hg} ; \mathrm{HCO}_{3} 12.9 \mathrm{mmol} \mathrm{L}^{-1}$; and a base excess (BE) of $-9.1 \mathrm{mmol} \mathrm{L}^{-1}$. The patient underwent gastric lavage with potassium permanganate $(1 / 10000)$ and was given intravenous sodium bicarbonate
$\left(\mathrm{NaHCO}_{3}\right) 44 \mathrm{mEq}$ every $15 \mathrm{~min}$. The patient was then admitted to our Centre (about three hours postingestion of AlP). Vital signs on arrival were: blood pressure 100/70 mm Hg; pulse $130 \mathrm{bpm}$; respiratory rate 18 per minute; and body temperature $37^{\circ} \mathrm{C}$ with an oxygen saturation of $96 \%$. Electrocardiography (ECG) revealed sinus tachycardia with no ST-T changes, but serial ECGs showed non-specific ST and $\mathrm{T}$-wave changes and interventricular conduction delay (Figure 1). Serial vital signs and laboratory data are shown in Table 1. The patient was admitted to the intensive care unit (ICU) and received intravenous crystalloid fluid (normal saline; $150 \mathrm{~mL} \mathrm{~h}^{-1}$ until her thirst was resolved), vasopressors (dopamine; $10 \mu \mathrm{g} \mathrm{kg}^{-1} \mathrm{~min}^{-1}$, and norepinephrine; $4 \mu \mathrm{g} \mathrm{min}^{-1}$ ), digoxin $0.5 \mathrm{mg}$ stat followed by $0.25 \mathrm{mg} \mathrm{q} 6 \mathrm{~h}$ for $24 \mathrm{~h}$ and $0.25 \mathrm{mg}$ daily, afterwards, glucagon $4 \mathrm{mg} \mathrm{h}^{-1}$, magnesium sulphate $2 \mathrm{~g}$ stat followed by $1 \mathrm{~g} \mathrm{q} 6 \mathrm{~h}$, sodium bicarbonate (until correction of metabolic acidosis), vitamin C $500 \mathrm{mg}$ per day, vitamin E $100 \mathrm{IU}$ per day, heparin 5000 IU BID and N-acetylsycteine $300 \mathrm{mg} \mathrm{kg}^{-1}$ through $24 \mathrm{~h}$ in three divided doses. About $24 \mathrm{~h}$ later, the patient experienced tachypnea (respiratory rate 45 per minute) and her $\mathrm{O}_{2}$ saturation dropped to $70 \%$.

The patient also complained of retrosternal discomfort and was therefore intubated and placed on mechanical ventilation with the following parameters: synchronised intermittent mandatory ventilation (SIMV) mode of fractional inspired oxygen $\left(\mathrm{FiO}_{2}\right)$ was $50 \%$, tidal volume was $350 \mathrm{~mL}$, and positive end-expiratory pressure (PEEP) was $7 \mathrm{~mm} \mathrm{H}_{2} \mathrm{O}$. However, her $\mathrm{O}_{2}$ saturation remained at $88-92 \%$ and gasometry showed an arterial oxygen pressure $\left(\mathrm{PaO}_{2}\right)$ level of $50 \mathrm{~mm} \mathrm{Hg}$. A chest X-ray confirmed acute respiratory distress syndrome (ARDS) (Figure 2). ARDS was defined as diminished $\mathrm{PaO}_{2}$ to $\mathrm{FiO}_{2}$ ratio (P to $\mathrm{F}$ ratio smaller than 200). Thirty-six hours after admission, bedside echocardiography showed a left ventricular ejection fraction (LVEF) of less than $20 \%$, global hypokinesia of the left ventricle and mitral valve regurgitation (MR) and an IABP was inserted by a cardiac surgeon. The patient had no contraindications to the use of an IABP (e.g., sepsis, aortic aneurysms, peripheral vascular diseases, neurological deficits, aortic dissection, etc.).

On the third day of ICU admission, ventilator acquired pneumonia (VAP) occurred and the patient's temperature increased to $38.5{ }^{\circ} \mathrm{C}$. Meropenem $(1 \mathrm{~g}$ three times per day), amikacin (500 mg BID), and vancomycin (1 g BID) were administered. On day 
Table 1 Clinical and paraclinical findings of our case of AlP poisoning

\begin{tabular}{|c|c|c|c|c|c|c|c|c|}
\hline $\begin{array}{c}\text { laboratory tests / time after } \\
\text { ingestion }\end{array}$ & $\begin{array}{c}\text { on } \\
\text { admission }\end{array}$ & $12 \mathrm{~h}$ & $24 \mathrm{~h}$ & day 5 & day 8 & day 10 & day 18 & day 26 \\
\hline Blood pressure (mm Hg) & $100 / 70$ & $90 / 60$ & $80 / 50$ & $105 / 65$ & $110 / 70$ & $105 / 80$ & $120 / 70$ & $115 / 80$ \\
\hline Pulse rate (bpm) & 130 & 160 & 150 & 110 & 86 & 90 & 103 & 98 \\
\hline Respiratory rate $(\mathrm{pm})$ & 20 & 30 & 45 & SIMV & SIMV & SIMV & 20 & 15 \\
\hline $\mathrm{O}_{2}$ saturation $(\%)$ & 94 & 86 & 70 & 91 & 100 & 100 & 96 & 95 \\
\hline $\mathrm{pH}$ & 7.48 & 7.30 & 6.90 & 7.47 & 7.49 & 7.38 & - & 7.42 \\
\hline $\mathrm{PaCO}_{2}(\mathrm{~mm} \mathrm{Hg})$ & 17.6 & 19.9 & 69 & 45 & 34.8 & 43.9 & - & 32.3 \\
\hline $\mathrm{PaO}_{2}(\mathrm{mmHg})$ & 58 & 52 & 50 & 56 & 60 & 62 & 65 & 65 \\
\hline Serum $\mathrm{HCO}_{3}\left(\mathrm{mmol} \mathrm{L}^{-1}\right)$ & 13.1 & 10 & 15.4 & 32.9 & 28.2 & 26.5 & - & 21.4 \\
\hline $\mathrm{WBC}\left(10^{3} \mu \mathrm{L}\right)$ & 16.5 & - & 23 & - & 23 & 22.6 & 14.1 & 4.4 \\
\hline $\mathrm{Hb}\left(\mathrm{g} \mathrm{dL}^{-1}\right)$ & 13.7 & - & 14.4 & - & 8.4 & 8.7 & 9 & 10 \\
\hline Platelet count $\left(10^{3} \mu \mathrm{L}\right)$ & 232 & - & 194 & - & 81 & 131 & 267 & 316 \\
\hline $\mathrm{Na}\left(\right.$ meq L $\left.\mathrm{L}^{-1}\right)$ & 140 & - & 139 & 144 & 139 & 136 & 138 & 140 \\
\hline $\mathrm{K}\left(\mathrm{meq} \mathrm{L}^{-1}\right)$ & 4 & - & 3.9 & 2.6 & 4.6 & 4.4 & 4.1 & 3.8 \\
\hline Prothrombin time (s) & 12.5 & - & - & - & 15.6 & 14.4 & - & 13.3 \\
\hline Creatinine $\left(\mathrm{mg} \mathrm{dL}^{-1}\right)$ & 0.6 & - & - & 0.8 & 0.8 & 0.7 & 0.6 & 0.9 \\
\hline Glucose $\left(\mathrm{mg} \mathrm{dL}^{-1}\right)$ & 145 & - & 485 & 45 & 169 & 155 & 135 & 109 \\
\hline Creatine phosphokinase (IU L-1) & 219 & - & - & - & 648 & 203 & - & 124 \\
\hline $\mathrm{AST}^{*}\left(\mathrm{IU} \mathrm{L}^{-1}\right)$ & 52 & - & - & - & & 72 & 43 & 45 \\
\hline $\mathrm{ALT}^{* *}\left(\mathrm{IU} \mathrm{L} \mathrm{L}^{-1}\right)$ & 75 & - & - & - & & 273 & 216 & 89 \\
\hline
\end{tabular}

STMV - synchronised intermittent mandatory ventilation

*Aspartate aminotransferase

**Alanine aminotransferase

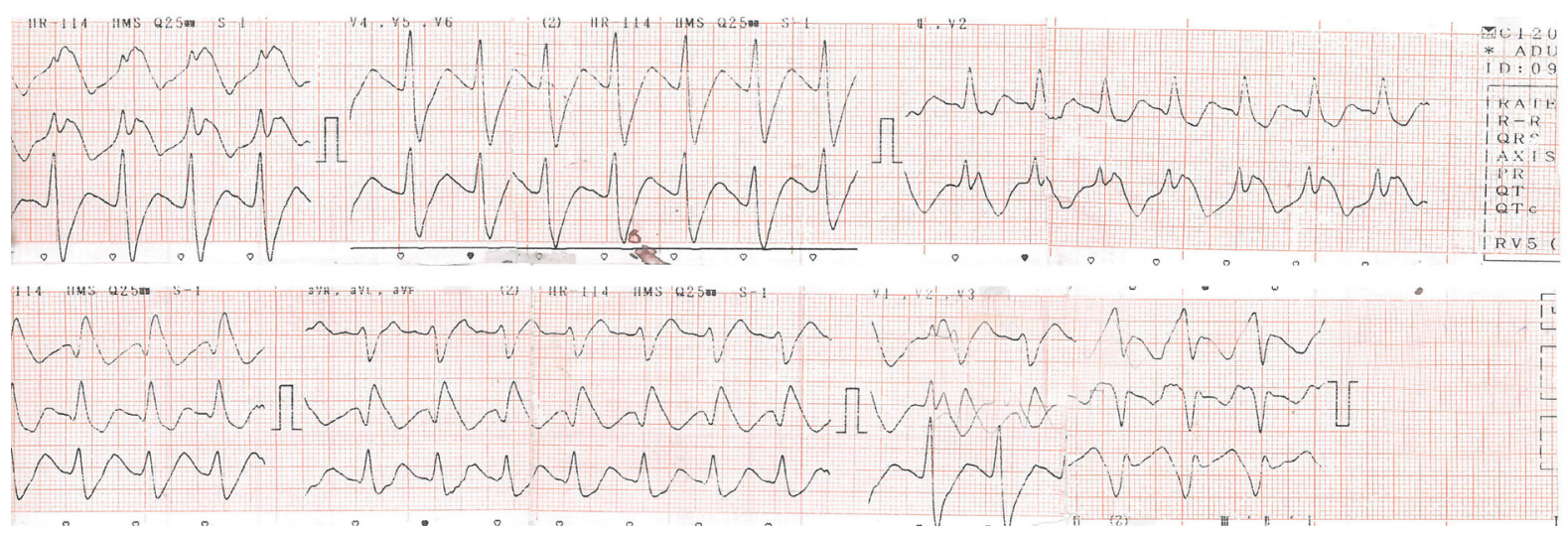

Figure 1 Electrocardiography of AlP poisoned case. Electrocardiography (ECG) revealed sinus tachycardia with no ST-T changes; but serial ECGs showed non-specific ST and T-wave changes and interventricular conduction delay

four, sudden complete cardiac arrest occurred; however, fortunately, the patient responded to resuscitation. After stabilization of vital signs, the IABP was removed ( 8 days after insertion). Repeated echocardiography on day 20 of admission showed an LVEF of $50 \%$.

Surprisingly, our patient exhibited thrombocytopenia, hypokalaemia, and variations in haemoglobin between the second and the eighth day of admission (Table 1), maybe due to receiving heparin. The administered antibiotics were the other possible causes of acute thrombocytopenia $(21,22)$. Hypokalaemia in our patient was probably due to the administration of sodium bicarbonate to correct acidosis, although there is evidence that AlP can affect potassium levels in cases of poisoning $(9,23)$. Variations in haemoglobin were probably due to haemolysis induced by the IABP as an external device. Mean corpuscular volume amounts have been reported to be at maximum levels 


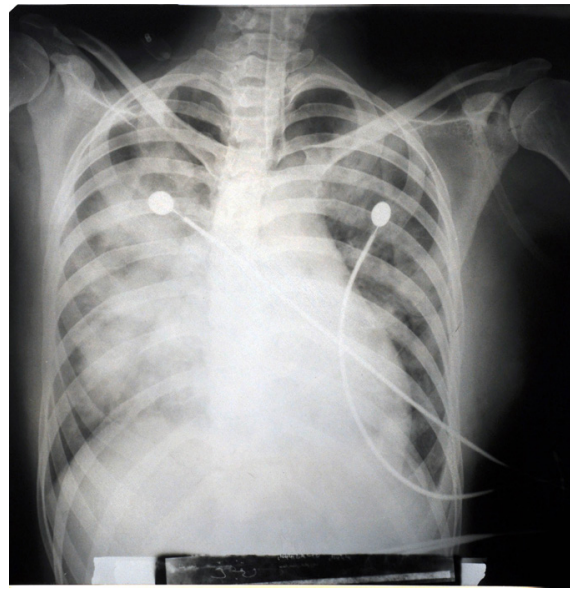

Figure 2 Chest $X$-ray of AlP poisoned case. Acute respiratory distress syndrome (ARDS)

due to the release of unmaturated red blood cells into circulation from bone marrow hyperactivity (24).

The patient's medication (vasopressors, calcium gluconate, magnesium sulphate, hydrocortisone, vitamin $\mathrm{C}$, and vitamin $\mathrm{E}$ ) was tapered gradually. After consultation with a psychologist, the patient was discharged on day 27 in good condition and normal vital signs and laboratory tests. A follow-up visit about two months later revealed that the patient was asymptomatic with no evidence of ongoing toxicity or sequelae.

\section{DISCUSSION}

Cardiogenic shock is defined as systolic blood pressure $<90 \mathrm{~mm} \mathrm{Hg}$ or $30 \mathrm{~mm} \mathrm{Hg}$ below the baseline during organ dysfunction (25). It is a kind of shock in which the failure of the cardiac ventricle causes inadequate circulation. It is defined by tissue hypoperfusion and hypotension and is a largely irreversible and fatal condition (26). Cardiogenic shock is commonly caused by damage to the heart muscle such as myocardial infarction, arrhythmias, cardiomyopathy, etc. Some cases of drug poisoning, such as those by $\beta_{1}$ adrenergic receptor antagonists (e.g. atenolol, propranolol) and calcium channel blockers, also lead to profound hypotension and cardiogenic shock; similar to those that occur with aluminium phosphide (27-29). Cardiogenic shock could also be approached by procedures such as administration of positive inotropic agents or glucagon $(11,30)$ and enhancing pumping capabilities, which should cause a positive inotropic and chronotropic effect by stimulating adenosine monophosphate.

Pumping can also be improved by using an IABP, a left ventricular assist device that enhances the perfusion of coronary arteries. During an IABP procedure, a balloon is inserted via the femoral artery and placed below the left subclavian and above the renal arteries (31). It is generally used in patients with heart failure waiting for heart transplantation, further revascularization, and shock. At the end of a systole, pumping the balloon causes an increase in aortic blood pressure and increases cardiac output and coronary perfusion as well as improves central nervous system perfusion.

There have been several cases of intoxication where an IABP was applied (27-29), all of which involved refractory cardiogenic shock. Janion et al. (32) reported successful treatment of combined massive drug intoxication using mechanical ventilation and IABP, concluding that combined mechanical and pharmacological treatment may even prevent multiorgan insufficiency.

The use of an IABP for the treatment of AlP was first reported by Chacko et al. (33) in 2008, in a 25-year-old female who suffered from severe toxicity after ingesting 10 tablets of AlP. Unfortunately, it was unsuccessful. A successful treatment of AlP with an IABP was first reported by Siddaiah et al. (12) in 2009, in a 22-year old female who, suffering with cardiogenic shock due to AlP poisoning, was treated with an IABP until the effects of AlP resolved. There are no other reports in the literature on IABP in the treatment of AlP poisoning and the case presented here was the second successful one in this regard.

Our use of an IABP for treating AlP-induced cardiogenic shock yielded success in a patient who otherwise appeared to have a very poor prognosis due to refractory hypotension and ARDS $(34,35)$. Given our success in the case reported here, it is reasonable to question why IABP has not been used more often. We assume that this most likely relates to the unavailability of a cardiac surgeon in Iranian referral toxicological centres and probably other countries where AlP poisoning is common. Furthermore, to improve outcomes, AlP-poisoned patients need extensive ICU care after insertion of an IABP and, due to the high rate of poisoned patients in the aforementioned countries, the lack of ICU beds is another limitation that should be considered.

IABP has also been used in severe LV dysfunction in other toxic myocarditis cases (27-30), as IABP 
generally reduces afterload and improves coronary artery perfusion. Despite many proposed therapies, patients with severe AlP poisoning continue to die of cardiogenic shock. We recommend the use of this treatment in other cases of refractory cardiogenic shock from AlP poisoning and encourage clinical toxicologists to report on their experiences.

\section{Acknowledgments}

The successful completion of this paper was facilitated by our balloon pump team comprising $\mathrm{Mr}$ Abdolali Ghazmeh and Mr Majid Heidari.

\section{REFERENCES}

1. Mehrpour O. Comment on "An update on toxicology of aluminum phosphide". DARU 2012;20:50. doi: 10.1186/2008-2231-20-50

2. Mehrpour O, Keyler D, Shadnia S: Comment on Aluminum and zinc phosphide poisoning. Clin Toxicol (Phila) 2009;47:838-9. doi: 10.1080/15563650903203684

3. Mehrpour O, Jafarzadeh M, Abdollahi M. A systematic review of aluminium phosphide poisoning. Arh Hig Rada Toksikol 2012;63:61-73. doi: 10.2478/10004-1254-63-20122182

4. Shadnia S, Mehrpour O, Soltaninejad K. A simplified acute physiology score in the prediction of acute aluminum phosphide poisoning outcome. Indian J Med Sci 2010;64:5329. PMID: 21258160

5. Shadnia S, Mehrpour O, Abdollahi M. Unintentional poisoning by phosphine released from aluminum phosphide Hum Exp Toxicol 2008;27:87-9. doi: $10.1177 / 0960327107086241$

6. Mehrpour O, Singh S. Rice tablet poisoning: A major concern in Iranian population. Hum Exp Toxicol 2010;29:701-2. doi: 10.1177/0960327109359643

7. Singh D, Dewan I, Pandey AN, Tyagi S. Spectrum of unnatural fatalities in the Chandigarh zone of north-west India: a 25 year autopsy study from a tertiary care hospital. J Clin Forensic Med 2003;10:145-52. PMID: 15275009

8. Bolter CJ, Chefurka W. Extramitochondrial release of hydrogen peroxide from insect and mouse liver mitochondria using the respiratory inhibitors phosphine, myxothiazol, and antimycin and spectral analysis of inhibited cytochromes. Arch Biochem Biophys 1990;278:65-72. PMID: 2321971

9. Mehrpour O, Alfred S, Shadnia S, Keyler DE, Soltaninejad K, Chalaki N, Sedaghat M. Hyperglycemia in acute aluminum phosphide poisoning as a potential prognostic factor. Hum Exp Toxicol 2008;27:591-5. doi: 10.1177/0960327108096382

10. Mehrpour O, Dolati M, Soltaninejad K, Shadnia S, Nazparvar B. Evaluation of histopathological changes in fatal aluminum phosphide poisoning. Indian J Forensic Med Toxicol 2008;2:34-6.

11. Mehrpour O, Farzaneh E, Abdollahi M. Succesfull treatment of aluminum phosphide with digoxin: a case report and review of literature. Int J Pharmacol 2011;7:761-4. doi: 10.3923/ijp.2011.761.764

12. Siddaiah L, Adhyapak S, Jaydev S, Shetty G, Varghese K, Patil C, Iyengar S. Intra-aortic balloon pump in toxic myocarditis due to aluminum phosphide poisoning. J Med Toxicol 2009;5:80-3. PMID: 19415593

13. Price NR, Moles KA, Humphires OA. Phosphine toxicity and catalase activity in susceptible and resistant strains of lesser grain borer (Rhyzopertha dominica). Comp Biochem Physiol Part C: Comp Pharmacol 1982;73:411-5. doi: 10.1016/0306-4492(82)90144-7

14. Pajoumand A, Jalali N, Abdollahi M, Shadnia S. Survival following severe aluminum phosphide poisoning. J Pharm Pract Res 2002;32:297-9.

15. Saidi H, Shokraneh F, Ghafouri HB, Shojaie SJ. Effects of hyperbaric oxygenation on survival time of aluminum phosphide intoxicated rats. J Res Med Sci 2011;16:1306-12. PMID: 22973324

16. Tehrani H, Halvaie Z, Shadnia S, Soltaninejad K, Abdollahi M. Protective effects of $\mathrm{N}$-acetylcysteine on aluminum phosphide-induced oxidative stress in acute human poisoning. Clin Toxicol (Phila) 2013;51:23-8. doi: 10.3109/15563650.2012.743029

17. Mehrpour O, Aghabiklooei A, Abdollahi M, Singh S. Severe hypoglycemia following acute aluminum phosphide (rice tablet) poisoning; a case report and review of the literature. Acta Med Iran 2012;50:568-71. PMID: 23109032

18. Zamani N, Mehrpour O. Protective role of G6PD deficiency in poisoning by aluminum phosphide; are there possible new treatments? Eur Rev Med Pharmacol Sci 2013;17:994-5. PMID: 23640450

19. Mehrpour O, Abdollahi M. Poison treatment centers in Iran. Hum Exp Toxicol 2012;31:303-4. doi : 10.1177/0960327110392086

20. Mehrpour O, Zamani N, Brent J, Abdollahi M. A tale of two systems: poisoning management in Iran and the United States. DARU 2013;21:42. doi: 10.1186/2008-2231-21-42

21. Ruggero MA, Abdelghany O, Topal JE. Vancomycin-induced thrombocytopenia without isolation of a drug-dependent antibody. Pharmacotherapy 2012;32:e321-5. doi: 10.1002/ phar.1132

22. Alegre Herrera S, Quirós Valera M, Rodríguez FernándezA. Trombocitopenia aguda por imipenem/cilastatina [Imipenem/ cilastatin-induced acute thrombocytopenia, in Spanish]. Med Clin (Barc) 2001;117:197-8. PMID: 11481089

23. Mehrpour O, Shadnia S, Soltaninejad K, Yaghmaei A. Evaluation of electrolytes and blood glucose level in aluminum phosphide poisoning. Sci J Forensic Med 2009; 15:49-53.

24. Ficek SJ, Stammers AH, Galbraith TA, Alonso A. Hemostatic assessment of patients undergoing intraaortic balloon pump therapy. J Extra Corpor Tech 1997;29:78-82. PMID: 10168534

25. Worthley LIG. Shock: A review of pathophysiology and management. Part I. Crit Care Resusc 2000;2:55-65. PMID: 16597285

26. Sarswat N, Hollenberg SM. Cardiogenic shock. Hosp Pract (Minneap) 2010;38:74-83.

27. Melanson P, Shih RD, De Roos F. Intra-aortic balloon counterpul-sation in calcium channel blocker overdose. Vet Hum Toxicol 1993;35:345.

28. Lane AS, Woodward AC, Goldman MR. Massive propranolol overdose poorly responsive to pharmacologic therapy: use 
of the intra-aortic balloon pump. Ann Emerg Med 1987;16:1381-3. PMID: 3688604

29. Gillard P, Laurent M. Dextropropoxyphene-induced cardiogenic shock: treatment with intra-aortic balloon pump and milrinone. Intensive Care Med 1999;25:335. PMID: 10229178

30. Hall-Boyer K, Zaloga GP, Chernow B. Glucagon: hormone or therapeutic agent? Crit Care Med 1984;12:584-9. PMID: 6375966

31. Wnek W. Zastosowanie kontrapulsacji wewnatrzaortalnej w terapii ciezkiej niewydolności krazenia w zatruciach lekami kardiotoksycznymi [The use of intra-aortic balloon counterpulsation in the treatment of severe hemodynamic instability from myocardial depressant drug overdose, in Polish]. Przegl Lek 2003;60:274-6. PMID: 14569902

32. Janion M, Stepień A, Sielski J, Gutkowski W. Is the intraaortic balloon pump a method of brain protection during cardiogenic shock after drug intoxication? J Emerg Med 2010;38:162-7. doi: 10.1016/j.jemermed.2007.10.037

33. Chacko J, Shivaprasad C. Fatal aluminium phosphide poisoning due to myocardial depression refractory to high dose inotropic support and intra-aortic balloon counterpulsation. Indian J Crit Care Med 2008;12:37-8. doi: 10.4103/0972-5229.40949

34. Siwach SB, Singh P, Ahlawat S, Dua A, Sharma D. Serum and tissue magnesium content in patients of aluminium phosphide poisoning and critical evaluation of high dose magnesium sulphate therapy in reducing mortality. J Assoc Physicians India 1994;42:107-10. PMID: 7860467

35. Wahab A, Zaheer M, Wahab S, Khan R. Acute aluminium phosphide poisoning: an update. Hong Kong J Emerg Med 2008;15:152-5 


\title{
Sažetak
}

\section{Primjena intra-aortne balonske pumpe pri kardiogenom šoku uzrokovanom trovanjem aluminijevim} fosfidom

\begin{abstract}
Aluminijev fosfid (AlP) visoko je toksičan pesticid koji inhibira citokrom c oksidazu i uzrokuje oksidacijski stres. Smrt nastupa nakon refraktornog kardiogenog šoka uslijed miokardijalne disfunkcije. Vrlo je malo literature o izvantjelesnim sredstvima održavanja na životu nakon otrovanja AlP-om. Iako postoji određeni broj terapija, nijedna ne vodi do potpunoga izlječenja. Prikazan je slučaj uporabe intra-aortne balonske pumpe (IABP) kod 24-godišnje žene otrovane namjernim uzimanjem AlP-a (3 g), što je uzrokovalo refraktorni kardiogeni šok i akutni respiratorni distres sindrom (ARDS). Pacijentici je želudac ispran kalijevim permanganatom, intravenozno je primila natrijev bikarbonat te je zbrinuta u jedinici za intenzivnu skrb. Ehokardiografija $36 \mathrm{~h}$ nakon uzimanja tablete AlP-a pokazala je ejekcijsku frakciju lijevog ventrikula (LVEF) od $<20 \%$. Nakon umetanja IABP-a vitalni su se znakovi su se poboljšali. Pumpa je uklonjena nakon osam dana, a dvadesetoga dana LVEF je iznosio $50 \%$. Naši rezultati pokazuju da bi primjena IABP-a mogla poboljšati prognoze pacijenata s refraktornim kardiogenim šokom uslijed teškog otrovanja s AlPom. Stoga preporučujemo kliničkim toksikolozima da razmotre ovaj novi tretman.
\end{abstract}

KLJUČNE RIJEČI: hitni medicinski tretman; izvantjelesna sredstva održavanja na životu; otrovanje pesticidom

\section{CORRESPONDING AUTHOR:}

\author{
Omid Mehrpour MD \\ Medical Toxicology and Drug Abuse Research Center (MTDRC) \\ University of Medical Sciences; \\ Pasdaran Avenue; Birjand; Iran \\ Email: omid.mehrpour@yahoo.com.au
}

